\title{
Conditional Cash Transfers, Civil Conflict and Insurgent Influence: Experimental Evidence from the Philippines*
}

\author{
Benjamin Crost $^{\dagger} \quad$ Joseph H. Felter ${ }^{\ddagger} \quad$ Patrick B. Johnston ${ }^{\S}$
}

August 11, 2015

\begin{abstract}
Conditional cash transfer (CCT) programs are an increasingly popular tool for reducing poverty in conflict-affected areas. Despite their growing popularity, there is limited evidence on how CCT programs affect conflict and theoretical predictions are ambiguous. We estimate the effect of conditional cash transfers on civil conflict in the Philippines by exploiting an experiment that randomly assigned eligibility for a CCT program at the village level. We find that cash transfers caused a substantial decrease in conflict-related incidents in treatment villages relative to control villages in the first nine months of the program. Using unique data on local insurgent influence, we also find that the program significantly reduced insurgent influence in treated villages. An analysis of possible spillovers yields inconclusive results. While we find no statistical evidence of spillovers, we also cannot rule out that the village level effect was due to displacement of insurgent activity from treatment to control villages.
\end{abstract}

${ }^{*}$ The authors thank Eli Berman, Christian Deloria, Radha Iyengar, Daniel Rees, Jacob Shapiro, and participants at the NBER Economics of National Security summer session and the Empirical Studies of Conflict (ESOC) Annual Meeting for comments on earlier versions. Felter and Johnston acknowledge support from AFOSR Award No. FA9550-09-1-0314. Any opinions, findings, conclusions, and recommendations expressed in this publication are the authors' and do not necessarily reflect AFOSR's views. Felter acknowledges financial support from the Office of Naval Research (ONR) through Award N000141110735 at the National Bureau of Economic Research.

$\dagger^{\dagger}$ Assistant Professor, Department of Economics, University of Colorado Denver, Campus Box 181, Denver, CO 80217-3364. Email: Benjamin.Crost@ucdenver.edu.

${ }^{\ddagger}$ Senior Research Scholar, Center for International Security and Cooperation, Stanford University, 616 Serra St., Stanford, CA 94305-6165. Email: joseph.felter@stanford.edu.

${ }^{\S}$ Political Scientist, RAND Corporation, 4570 5th Ave., Pittsburgh, PA $15213 . \quad$ Email: Patrick_Johnston@RAND . org. 


\section{Introduction}

Since the end of World War II, over half of all countries in the world experienced civil conflicts (Blattman and Miguel, 2010), leading to the deaths of more than 16 million people and the destruction of immense amounts of physical capital (Fearon and Laitin, 2003). In addition to these direct effects, conflict causes lower levels of economic growth (Abadie and Gardeazabal, 2003; Lopez and Wodon, 2005) education (Leon, 2012) and adverse health outcomes like low birth weight (Ghobarah et al., 2004; Camacho, 2005; Mansour and Rees, 2012). Overall, conflict-affected countries have had substantially lower rates of poverty reduction and have made slower progress towards achieving the Millennium Development Goals (World Bank, 2012). In response to these findings, there have been calls for an increase in development assistance to conflict-affected countries, most prominently from the World Bank (World Bank, 2012).

The effect of aid on conflict, however, remains largely unknown. Empirical evidence that aid can reduce conflict comes from Berman et al. (2011a), who find that small-scale aid and reconstruction spending disbursed by the US Army in Iraq led to a decrease in violence against US forces and civilians. There are two potential mechanisms that may explain this

effect. First, aid may increase popular support for the government by "winning hearts and minds." This may make the population more likely to provide information on insurgents to government forces, better enabling them to capture or kill insurgents and reduce insurgent attack rates (Berman et al., 2011a). Second, aid programs may increase the opportunity cost of joining an insurgency by boosting the local economy and creating higher returns to peaceful activities.

However, recent evidence suggests that aid can also exacerbate conflict by creating incentives for looting and strategic retaliation. For instance, Crost et al. (2014) find that infrastructure 
spending in the form of community-driven development (CDD) projects increased conflict in the Philippines; Khanna and Zimmermann (2014) find that a rural employment program increased conflict in India; ${ }^{1}$ and Nunn and Qian (2014) find that US food aid increased conflict in recipient countries. Given the mixed evidence on the effect of aid on conflict so far, an important economic question with significant policy relevance is therefore how aid can be delivered in a manner that reduces poverty without exacerbating conflict.

This study examines the effect of a large conditional cash-transfer (CCT) program - the Philippines' Pantawid Pamilyang Pilipino Program (hereafter referred to as Pantawid Pamilya) - on civil conflict. CCT programs distribute cash payments to poor households that meet a number of prerequisites and conditions, such as child vaccinations and school attendance. Over the past decade they have become one of the most important modes of delivering development aid and a large literature documents their positive impact on the well-being of the poor (Fiszbein and Schady, 2009). However, little is known about the relationship between CCT programs and civil conflict. ${ }^{2}$ Understanding this relationship is both a timely and important issue: CCT programs are currently operating in numerous conflict-affected countries including Colombia, India, Indonesia and the Philippines, and are increasingly being used to deliver aid to displaced persons in conflict zones (UNHCR, 2012).

Our analysis exploits a randomized experiment conducted by the World Bank in 2009. ${ }^{3}$ In

\footnotetext{
${ }^{1}$ However, Fetzer (2014) finds that the same program decreased the relationship between rainfall and conflict, suggesting that the program reduced conflict in years of drought.

${ }^{2} \mathrm{~A}$ recent study found that the Brazilian CCT program Bolsa Familia led to a reduction in crime, mostly in the form of robberies and drug-related offenses (Chioda et al., 2012). However, it is difficult to extrapolate from the behavior of individual criminals to the behavior of insurgent organizations that act strategically and pursue political goal on a large scale. For example, Crost et al. (2014) find evidence that CDD projects increased conflict in the Philippines because insurgent groups sabotaged these projects in order to derail their successful implementation and avoid an anticipated shift in popular support towards the government. It is therefore possible that aid programs might reduce crime, perhaps by increasing the opportunity cost of criminal behavior, but increase civil conflict because insurgents have an incentive to sabotage them because successful implementation would undermine their position.

${ }^{3}$ Data from this experiment has been previously used to estimate the effect of Pantawid Pamilya on household and individual level outcomes such as consumption, education and health (Chaudhury et al., 2013), and on electoral support for incumbent politicians (Labonne, 2013).
} 
this experiment, 130 villages in 8 municipalities of the Philippines were randomly divided into a treatment group, which began receiving transfers through the program in 2009, and a control group, which did not receive transfers until 2011. Using a unique village-level dataset on conflict incidents reported by the Armed Forces of the Philippines (AFP) - the most comprehensive data source on conflict in the Philippines - we estimate the causal effect of CCTs on conflict by comparing the intensity of violence in treatment and control villages before and after the start of the program. We further exploit the fact that the 8 municipalities in which the village-level experiment took place were randomly chosen out of a set of 19 eligible municipalities. We compare the 8 experimental municipalities, who received the program in only half of their villages, to the remaining 11 municipalities, who were fully covered by the program, to test for evidence of spillover effects on nearby untreated villages.

In addition, we estimate the effect of Pantawid Pamilya on local insurgent influence, using data from comprehensive assessments made by the Philippine military. It is important to understand the effect of different types of aid on this outcome because insurgent influence can have substantial negative consequences even in the absence of violence. ${ }^{4}$ The presence of insurgents can depress economic activity by eroding the rule of law and creating insecure property rights that may disincentivize investment (Berman et al., 2012). In addition, insurgents often levy taxes on the population, imposing an additional burden on economic activity (Weinstein, 2006; Berman et al., 2012). In the Philippines, rebel extortion activities known as "revolutionary taxes" imposed by the New People's Army (NPA) on businesses discourage investment and permit the rebels to extract rents from areas where they wield influence (International Crisis Group, 2011; Quimpo, 2014). A program that reduces violence by weakening insurgent influence is therefore likely to have more beneficial long-term effects than a program that merely reduces incentives to commit acts of violence but does

\footnotetext{
${ }^{4}$ For a survey of the qualitative evidence for negative economic and welfare consequences of insurgent influence, see Kalyvas (2006). On insurgent influence and predation, see also Fearon (2008); Berman et al. (2012).
} 
not affect the local influence of insurgents.

Our analysis finds that CCTs led to a substantial decrease in conflict incidents in treated villages in the first year of the program, and a smaller and statistically insignificant decrease in the second year. We further find evidence that treated villages experienced a decrease in insurgent influence compared to control villages, suggesting that the program weakened rebel presence. To our knowledge, this is the first experimental evidence of the effect of CCTs on conflict $^{5}$ and the first evidence of the effect of any development program on local insurgent influence. The results of the municipal level analysis are inconclusive: we find no statistically significant evidence that municipalities in which the program was fully implemented in all villages experienced a decrease in conflict relative to municipalities in which only half of the villages received the program, and large standard errors do not allow us to rule that the program had a sizable conflict-increasing or conflict-decreasing effect at the municipality level. This means that we cannot rule out the possibility that the program's village-level effect was due to displacement of conflict from treatment to control villages.

Our findings suggest that the effect of CCT programs differ from those of other types of aid interventions, notably community-driven development, rural employment projects and food aid, which recent studies have found to increase conflict (Crost et al., 2014; Khanna and Zimmermann, 2014; Nunn and Qian, 2014). ${ }^{6}$ We discuss possible reasons for this difference in the concluding section. More broadly, our results imply opportunities for future research to evaluate how different types of aid programs influence the risk of violent conflict.

\footnotetext{
${ }^{5}$ There is, however, recent non-experimental evidence that CCTs increased conflict in Colombia (Weintraub, 2014).

${ }^{6}$ However, Beath et al. (2011) found little evidence that CDD programs affected insurgent violence in their evaluation of Afghanistan's National Solidarity Program.
} 


\section{Institutional Background}

\subsection{The Pantawid Pamilya Program}

This paper studies the Pantawid Pamilya program, a conditional cash-transfer program implemented by the Philippine government's Department of Social Welfare and Development (DSWD) and partly funded through loans from the World Bank and the Asian Development Bank. Since it began in 2007, the program financed transfers to approximately one million households in 782 cities and municipalities in 81 provinces in all 17 regions of the Philippines. ${ }^{7}$ It is currently the country's flagship antipoverty program.

Pantawid Pamilya is similar to numerous other CCT programs, such as Mexico's Oportunidades and Brazil's Bolsa Familia. Like these programs, Pantawid Pamilya is intended to reduce poverty and promote human capital investment by providing cash transfers to poor households on the condition that they satisfy basic health and education requirements. In order to receive transfers, recipient households are required to ensure their children attend school and receive a variety of vaccinations and deworming treatments. Pregnant women are required to receive regular pre- and post-natal health check-ups.

Households are eligible for transfers through the program if their per capita income is below the regional poverty line and they have children aged 0-14. Per capita incomes are estimated by a Proxy-Means Test (PMT) based on the following indicators: household consumption; education of household members; occupation; housing conditions; access to basic services; ownership of assets; tenure status of housing; and regional dummy variables. ${ }^{8}$ Finally, the lists of households identified by the PMT are validated through spot-checks and community

\footnotetext{
${ }^{7}$ These statistics were current as of January 2011. See Arulpragasam et al. (2011).

${ }^{8}$ The PMT's formula is not disclosed publicly, in order to minimize the chances of strategic reporting of census data.
} 
assemblies (Usui, 2011). The program was initially targeted to municipalities with a poverty incidence greater than $50 \%$, so that a large share of the population was eligible for the cash transfers. For instance, approximately $52 \%$ of all households were eligible for transfers in the villages that made up the experimental sample (Redaelli, 2009).

During the period studied, Pantawid Pamilya transfers amounted to a substantial fraction of the household income of program participants. The maximum transfer amount corresponded to 23 percent of the national poverty line; households above the poverty line were ineligible for the program. Families with three or more eligible children received the maximum annual grant of PHP 15,000, as long as they met the program's conditions; the minimum annual grant was PHP 8,000 to families with only one child. ${ }^{9}$ This transfer size was comparable to CCT programs in Latin America. In the well-known Mexican CCT program Oportunidades, the transfer size was approximately 21 percent of total annual household expenditures; in the Colombian CCT program Familias en Accion, transfers represented about 15 percent of the minimum wage; and in the Nicaraguan CCT program Red de Proteccion Social, transfers were about 17 percent of annual household expenditures (Fernandez and Olfindo, 2011, p. 6). The relatively large size of the transfers created a strong incentive to comply with the program conditions. In the villages covered in "Set 1" of the program, from which the experimental sample was drawn, 87 percent of eligible households complied with the program's conditions and received transfers (Fernandez and Olfindo, 2011, pp. 8-9).

The World bank's impact evaluation found evidence that the program was successful in increasing school enrollment and child nutritional outcomes, but no evidence that it increased household consumption, labor supply or fertility Chaudhury et al. (2013). There is also evidence that the program led to an increase in popular support for incumbent mayors Labonne (2013).

\footnotetext{
${ }^{9}$ At current exchange rates, Pantawid Pamilya transfers ranged from roughly $\$ 200$ to $\$ 370$.
} 


\subsection{Civil Conflict in the Philippines}

The Philippines are home to multiple long-running insurgencies with distinct motives and characteristics. The main insurgent groups are the New People's Army (NPA), the Moro Islamic Liberation Front (MILF), the Abu Sayyaf Group (ASG), and loosely connected criminal organizations referred to by the Armed Forces of the Philippines (AFP) in its reporting as "Lawless Elements" (LE). Table 1 shows the distribution of incidents nationwide and in Pantawid Pamilya experimental villages.

The country's largest and most active insurgent organization during the 2001-2010 period of study was the Communist Party of the Philippines (CPP) and its armed wing, the New People's Army (NPA). The NPA's strength averaged approximately 7,000 fighters over this period, and the group was active in 63 of the country's 73 provinces. ${ }^{10}$ Over 60 percent of the incidents reported by the AFP involved the NPA. In the villages that took part in the Pantawid Pamilya experiment, the NPA was involved in 72.1 percent of reported incidents.

The country's second-largest active insurgent movement during the period of study was the Moro Islamic Liberation Front (MILF), an Islamist separatist movement active in the southwestern provinces on the island of Mindanao. Between 2001 and 2010, the MILF was involved in 11 percent of security incidents reported by the military nationwide and 9.6 percent of incidents in the villages studied.

The remaining incidents involved insurgent splinter groups and criminal groups that the AFP refers to as Lawless Elements, who were involved in just under 19 percent of nationwide incidents and 18.3 percent of incidents in the villages under study. Finally, the al-Qaedaassociated Abu Sayyaf Group (ASG) were involved in 5 percent of the incidents reported by

\footnotetext{
${ }^{10}$ Estimates based on information maintained by the Armed Forces of the Philippines Deputy Chief of Staff for Intelligence (J2).
} 
the military nationwide during this period, but were not involved in any of the incidents in the villages under study. ${ }^{11}$

\section{Empirical Strategy}

We exploit a randomized experiment conducted by the World Bank starting in 2009 to identify the effect of CCTs on civil conflict. In the experiment, 130 villages were randomly divided into 65 treatment villages and 65 control villages. ${ }^{12}$

The experimental sampling followed a three-step procedure. First, four provinces (Lanao del Norte, Mountain Province, Negros Oriental, and Occidental Mindoro) were selected from a pool of eight provinces that were scheduled to begin receiving the Pantawid Pamilya program in 2009. These provinces were non-randomly selected on the basis of geography to ensure that the evaluation would cover areas in each of the country's three major island groups, Luzon, Visayas, and Mindanao (Redaelli, 2009, p. 20). Within these provinces, 19 municipalities were eligible to receive transfers through the Pantawid Pamilya program. Out of these, eight municipalities were randomly selected to be part of the experiment. Finally, half of the villages within each of the eight experimental municipalities were randomly assigned to the treatment group and the other half to the control group, leading to a sample of 65 treatment villages and 65 control villages. The treatment villages received transfers starting in 2009, while the control villages did not receive them until 2011. The remaining 11 eligible municipalities began receiving transfers in 2009.

Table 2 contains information on the treatment assignment of villages in each of the eight

\footnotetext{
${ }^{11}$ The Abu Sayyaf Group operates mainly in remote areas of Basilan and Sulu provinces, which did not take part in the experimental evaluation since Pantawid Pamilya was already operating in both provinces by late 2008 .

${ }^{12}$ Details of the experiment are described in Redaelli (2009); Chaudhury et al. (2013); Labonne (2013).
} 
experimental municipalities. Overall, the experimental villages contain 47,627 households, out of which 24,651 were eligible for the Pantawid Pamilya program (Redaelli, 2009). The four selected provinces are not the most conflict-affected ones in the Philippines, but all of them experience substantial amounts of conflict-related incidents. ${ }^{13}$

The timeline of the experiment, as described by Chaudhury et al. (2013), was as follows. The randomization took place in October 2008 and the first cash transfer payments were made in April 2009. An endline survey was conducted in October and November of 2011 and the program began implementation in the control villages in December 2011. ${ }^{14}$ Of note, operating units in the Armed Forces of the Philippines reportedly did not coordinate with the Department of Social Welfare and Development officials responsible for implementing the Pantawid Pamilya program to shift forces and provide additional security in areas where the program was implemented. This makes it unlikely that the reduction in violence observed in barangays/villages receiving cash transfers was a result of increased security measures in the area. ${ }^{15}$

Since previous evidence suggests that the effect of development programs on conflict is highly heterogeneous across the different phases of the program (Crost et al., 2014), we separately analyze 4 different time periods: pre-randomization (before October 2008), postrandomization but pre-implementation (October 2008 - March 2009), early implementation (April - December 2009), and late implementation (all of 2010). We test robustness to different definitions of early and late implementation period in Section 4.3 below.

Our baseline specification is based on a simple comparison of treatment and control villages

\footnotetext{
${ }^{13}$ The average number of incidents in the experimental villages is only slightly below the national average in the pre-program period.

${ }^{14}$ Since our conflict data is limited to the period 2001-2010, we cannot exploit the phase-in of the control villages for our estimates.

${ }^{15}$ Multiple interviews by author with Armed Forces of the Philippines officials familiar with the Pantawid Pamilya program and the command and control of AFP units operating in the areas where the program was implemented.
} 
at different times during the relevant time-period, using the village-month as the unit of observation.

$$
\begin{array}{r}
Y_{\text {imt }}=\beta_{0}+\beta_{1} \text { Treat }_{i} \times \text { Pre }_{t}+ \\
\beta_{2} \text { Treat }_{i} \times \text { PostRand }_{t}+\beta_{3} \text { Treat }_{i} \times \text { EarlyImp }_{t} \\
+\beta_{4} \text { Treat }_{i} \times \text { LateImp }_{t}+\beta_{2} X_{i}+\eta_{m}+\lambda_{t}+\epsilon_{i m t}
\end{array}
$$

where $Y_{i m t}$ is the number of conflict incidents village $i$ in municipality $m$ experienced in month $t$, Treat $_{i}$ is an indicator variable for villages assigned to the treatment group, and

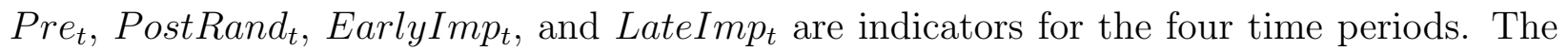
model further controls for a set of observed pre-treatment village characteristics $\left(X_{i}\right)$ and municipality and month fixed effects $\left(\eta_{m}\right.$ and $\left.\lambda_{t}\right)$. The parameter $\beta_{1}$ captures the pre-treatment difference in conflict incidents between treatment and control villages. The parameters $\beta_{2}$ through $\beta_{4}$ capture the causal effect of the Pantawid Pamilya program in the three postrandomization time-periods. Standard errors are clustered at the village level to account for possible serial correlation of the error term. ${ }^{16}$

In addition, we estimate a difference-in-differences specification, that uses the pre-randomization period as a baseline to control for unobserved differences between treatment and control villages. While these unobserved differences should be uncorrelated with the random treatment, they could still increase the variance of the error term, so that the difference-in-differences approach allow us to increase the precision of our estimates.

\footnotetext{
${ }^{16}$ It is also possible that error terms are correlated across space, for example within municipalities. To account for this, we cluster standard errors at the municipality-year level in the difference-in-differences approach described below.
} 
$Y_{\text {imt }}=\beta_{0}+\beta_{2}$ Treat $_{i} \times$ PostRand $_{t}+\beta_{3}$ Treat $_{i} \times$ EarlyImp $_{t}+\beta_{4}$ Treat $_{i} \times$ LateImp $_{t}+\alpha_{i}+\eta_{m t}+\epsilon_{i m t}$

where $\alpha_{i}$ and $\eta_{m t}$ are village and municipality-by-month fixed effects, and the remaining variables are defined as above.

\section{Results}

\subsection{Data, Summary Statistics and Balance Tests}

Data on conflict-related incidents were compiled from unclassified portions of the reports submitted by operating units of the AFP deployed to conduct counterinsurgency and other internal security operations in the field. The data includes information on every operational incident recorded by the AFP Joint Operations Center in the experimental villages during the period 2001-2010. One concern about this data is that it is self-reported by AFP troops who are themselves party to the conflict and may therefore have incentives to misreport incidents, and this should be kept in mind when interpreting the results (Crost et al., 2014). While misreporting is difficult to rule out, it is not unique to data from armed forces. Most studies of civil conflict rely on reports from newspapers or humanitarian agencies, which also have incentives to selectively report incidents and may have limited access to the activities of operational military units.

The main dependent variable used in this study is a monthly count of conflict incidents reported to have occurred within the geographic boundaries of each village in the sample. 
Table 3 lists several of the most commonly reported security incidents during this time period along with a description of the nature of these incidents. The majority of security incidents reported by the AFP do not lead to fatalities or other casualties. For example harassing fires directed at a military outpost may not be effective and an assassination -or "liquidation"attempt will often fail to succeed in inflicting any actual harm. It is likely that some incidents may go unreported or underreported such as insurgent violence initiated in areas where no government presence is available to report them. The conflict related incidents reported by Philippine military, however, are the most accurate proxy available for measuring the scope and intensity of civil conflict in an area. Similar type incident counts have been used in previous studies to approximate violence (Berman et al., 2011a,b, 2013; Beath et al., 2011; Condra and Shapiro, 2012; Dube and Vargas, 2013). In Appendix A, we also report estimates for casualty counts, which have been used by Crost et al. (2014) to study the effect of a Community-Driven Development program on conflict in the Philippines. However, the low number of casualties in the experimental villages during the period of observation makes these estimates very imprecise and less informative than those for incident counts.

The second dependent variable is a measure of insurgent influence in 2009 and 2010, the two years of the experiment. This variable measures the extent to which villages were influenced by insurgents according to assessments made by military field operatives in support of their campaign planning. ${ }^{17}$ Village level insurgent influence is assessed on the following four point scale - in order from highest to lowest degree of influence:

Category 3: Villages characterized by a permanent rebel presence in the village with rebels at times observed carrying arms openly and in some cases conducting military training among their members. Three of the 260 village year observations are assessed in this category.

\footnotetext{
${ }^{17}$ For a description and summation of how communist insurgents in the Philippines exert influence and indicators of this influence at the village level see Felter (2006).
} 
Category 2: Villages where insurgents are making efforts to organize village members, conducting propaganda activities and recruitment. No armed groups were visible in these villages and no military training was being openly conducted. Six village year observations in sample studied are are assessed in this category.

Category 1: Philippine military intelligence officials classified villages in this category when local intelligence indicated that they were in danger of being targeted by insurgents but did not currently have an overt presence of armed rebels or indications of organizing, recruitment or propaganda activities. 31 village years studied are assessed in this category.

Category 0: Villages deemed not under the influence 220 of the 260 total village years in the sample were deemed not to be under insurgent influence during the period studied.

Data on village treatment assignment in the experiment come from Pantawid Pamilya program data, which is maintained by the Philippine Department of Social Welfare and Development (DSWD). Finally, data on village characteristics come from the Philippines' 2000 National Census.

Table 4 presents summary statistics and balance tests for village-level control variables. The control variables consist of village population and indicators for the presence of paved streets, electricity, a communal water system, one or more health clinics or hospitals. All variables except for conflict incidents, insurgent influence, and treatment status are from the 2000 National Census of the Philippines.

The first two columns show means for treatment and control villages separately. The last column shows $p$-values from $t$-tests for differences in these means. The results show that treated villages had slightly more conflict-related incidents in the pre-treatment period. They also suggest that treated villages have slightly worse infrastructure than control villages, as 
they are less likely to have paved streets, electricity and stores, and more likely to have a communal water system. ${ }^{18}$ However, these differences are not statistically significant at conventional levels, which add to our confidence that the randomization was successful.

The summary statistics show that the average number of conflict incidents per village in the study area is relatively low. In the pre-treatment period 2001-2008, villages experienced on average approximately 0.0058 conflict incidents per month ( 0.07 per year). This is slightly above the average for the entire country of 0.064 incidents per village per year. While this might seem like a small number of incidents it does not necessarily indicate an unusually low intensity of conflict. For comparison, Beath et al. (2011) report that the villages in their experimental study of aid and conflict in Afghanistan experienced an average of only 0.02 conflict incidents within $1 \mathrm{~km}$ of the village in the entire period of observation, 20042007 (and an average of only 0.2 incidents within $10 \mathrm{~km}$ of the village). The average yearly number of incidents per village in our study areas is therefore higher than in certain regions of Afghanistan before US troop surge began in 2009. ${ }^{19}$

One concern about the small average number of incidents is that outliers with a large number of incidents in a single month may have a disproportionate effect on our estimates. Figure 2 shows the distribution of monthly incident counts (conditional on having any incidents), in the four time periods. The graph shows that, while the majority of villages have at most one incident per month, some observations have up to 6 . To test whether these observations drive our estimates, the results below also report regressions that use an indicator for having any incidents in a given month as the outcome of interest (since this variable is binary, it cannot be influenced by outliers). Of course, a limitation of our study is that the experiment

\footnotetext{
${ }^{18}$ Communal water systems are more likely to be present in poorer villages, while richer villages are likely to have piped water access to individual household.

${ }^{19}$ Furthermore, a low level of violence does not mean that a conflict is economically insignificant (Abadie and Gardeazabal, 2003; Murdoch and Sandler, 2004). Apart from the lives and resources lost to violence, the mere presence of insurgents distorts economic incentives, by increasing entrepreneurial risks and/or imposing an implicit tax from extortion and bribes paid to insurgents for protection.
} 
was not designed to study the effect of Pantawid Pamilya on conflict and therefore has a smaller sample size than would be optimal for such a study. Given the low baseline intensity of the conflict, our results are therefore necessarily based on a relatively small number of incidents and this should be kept in mind when interpreting our estimates.

\subsection{Conditional Cash Transfers and Conflict Intensity}

As explained in Section 3, we identify the causal effect of Pantawid Pamilya on conflict using data from a randomized control trial of 130 villages in eight randomly-selected municipalities in four provinces that took place starting in 2009.

Figure 3 shows trends in the average number of incidents experienced by treatment and control villages over the period 2001-2010. The figure shows that the treatment and control group had relatively steady and almost identical levels of conflict in the period 2001-2006. In 2007-2008, both groups experienced an upward trend, which was slightly steeper for the treatment group. In 2009, when the program was implemented in treatment villages, the number of conflict incidents in these villages dropped sharply. In contrast, conflict continued on the same upward trend that it had followed during the previous years in control villages. In 2010, the second year of the experiment, the program's effect appears to be smaller, as conflict increased in the treatment villages and decreases in the control villages. The increase in conflict in the control villages between 2008 and 2009 raises the possibility that some of the reduction in conflict in the treatment villages was due to displacement, which we discuss in Section 4.5 below.

Columns 1 and 2 of Table 5 display the results of equation 1 in section 3 using the monthly number of incidents as the outcome. Columns 3 and 4 report estimates of the same equation with an indicator for having experienced any incidents in a given month as the outcome. 
The coefficient associated with the treatment indicator can be interpreted as the causal effect of the Pantawid Pamilya program in the given time period. The results show that the program had a large, negative, statistically significant effect during the first nine months of its implementation in 2009. The estimated effect is robust to the inclusion of control variables (Column 2). The point estimates suggest that the program reduced conflict by between 0.012 and 0.014 incidents per village per month (between 0.14 and 0.17 per year). The estimated effect for the late implementation period is smaller and not statistically significant, which suggests that the program's effect may have been temporary (though the large standard errors do not allow us to rule out that the effect was of similar size in both periods). We find no evidence that the Pantawid Pamilya program had an effect on conflict during the period after the randomization took place but before implementation began.

Table 6 reports results of the difference-in-differences regression described in equation 2 . The results are similar to the ones of the simple OLS regressions. Column (1) shows that treated villages experience a decrease in conflict-related incidents during the implementation period. While this effect is only statistically significant for the early implementation period, an F-test can reject the null-hypothesis that the sum of effects in the early and late implementation periods is equal to zero. Column (4) shows similar results using the indicator for having experienced any incidents in a given month as the outcome.

Columns (2), (3), (5) and (6) of Table 6 test for heterogeneity between regions with high/low levels of baseline conflict. To do this, we separately estimated equation 2 for municipalities with above/below median numbers of conflict-related incidents in the pre-program period. The results suggest that the conflict-decreasing effect in the early implementation period is similar for regions with high and low baseline conflict. In the late implementation period, the effect appears to be more persistent in regions with low baseline violence, while regions with high baseline violence do not experience a conflict-reducing effect. However, given the relatively large standard errors associated with these estimates, we are unable to reject the 
hypothesis that there is no heterogeneity between regions with high and low baseline conflict.

\subsection{Timing of the Effect}

Table 7 reports estimates of equation 2 for different definitions of the early and late implementation phase. Our baseline specification reported above defined early implementation as the first 9 months after the start of the program, and late implementation as everything thereafter. To test robustness of our results to this definition of early and late implementation period, Table 7 reports results for regressions that define early implementation as 3 , 6, 9, 12 and 15 months after the start of the program. The results show that the effect is largest in the very early phase of the program's implementation and then declines gradually. Still, we find that the program had a statistically significant (at the $5 \%$ level) negative effect on the number of incidents for a time period that extends until 18 months after the start of implementation.

\subsection{Conditional Cash Transfers, Insurgent Influence and Casual- ties}

As additional evidence, we present an analysis of the CCT program's effect on the extent of insurgent influence and the number of casualties. As described in Section 4.1, the insurgent influence variable comes from assessments by the AFP in support of its counterinsurgency campaign planning and is coded on a scale from 0 to 3. To estimate the effect of Pantawid Pamilya on insurgent influence, column (1) in Table 8 reports an ordered probit regression of the insurgent influence variable on the treatment indicator. ${ }^{20}$ The results indicate that

\footnotetext{
${ }^{20}$ We currently do not have access to influence data for individual villages before 2009, and can therefore not carry out the same difference-in-differences analysis as for the incident count.
} 
insurgent influence is significantly lower in treated villages during the experimental period 2009-2010. This suggests that the program not only reduced violence but also led to a decrease in local insurgent influence. Columns (2)-(4) estimate the effect of the program on the probability of having insurgent influence above different thresholds. The results suggest that the program led to a decrease in insurgent influence at the extensive as well as the intensive margins, though none of the effects are individually statistically significant.

Table 9 presents estimates of the effect of Pantawid Pamilya on the number of casualties. The results show that the number of casualties decreased in treatment villages relative to control villages. However, the effect - while large relative to the pre-treatment mean - is not statistically significant. This is most likely due to the small number of casualties that occur in the experimental villages during the period of observation, which leads to a relatively noisy estimate of the effect.

\subsection{Were There Spillover Effects?}

One possible explanation for our results is that the Pantawid Pamilya program caused conflict to shift from treated villages to other nearby villages. Insurgents may, for example, have moved their combatants out of treated villages, perhaps because of increased presence of government troops or media scrutiny. It is therefore possible that the program did not decrease aggregate conflict in the country as a whole but merely shifted it from one location to another, as insurgents who moved out of treated villages initiated attacks in their new locations.

To estimate the size and sign of a possible spillover effect, we follow two different approaches. First, we use an approach similar to that of Miguel and Kremer (2004) and estimate the effect of being in spatial proximity to treated villages, regardless of own treatment status. To 
do this, we add interactions of the program time-periods with the number of treated villages within a certain radius $(3,5$ and 7 kilometers) to the right-hand side of the difference-indifferences regression. Of course, the number of nearby treated villages is not randomly assigned since it depends on the total number of villages within the radius, so that it will be negatively correlated with the remoteness of the village. To control for this, we also include the total number of experimental villages within the radius, again interacted with the program time-periods. Holding the total number of nearby experimental villages constant, the number of treated villages is random, so that this regression allows us to estimate the program's causal spillover effect. We also carry out a spillover analysis using insurgent influence as the dependent variable. Since we do not have access to insurgent influence data for individual villages before 2009, the analysis is carried out as an OLS regression that estimates the effect of the number of treated villages within the radius while controlling for the total number of experimental villages within the same distance.

The results reported in Table 10 suggest that villages within 3 kilometers of a treated village experienced 0.0036 fewer incidents per month during the early implementation period and 0.0070 fewer incidents per month in the late implementation period. These estimates are statistically significant at the 5\% level. This suggests that the Pantawid Pamilyia program appears to have conflict-reducing spillover effects to nearby villages. However, this spillover effect dissipates quickly, so that having treated villages within 5 or 7 kilometers does not lead to a statistically significant decrease in conflict (columns (2) and (3)). Results for insurgent influence as the dependent variable are similar. As with incident counts, there is evidence for negative spillovers on villages within 3 kilometers of a treated village, and the point estimates become smaller and not statistically significant for the larger distances. Overall, our results provide no evidence that the direct effect of the program on treated villages is due to displacement of conflict to nearby villages. It is of course difficult to rule out that conflict was displaced to distant villages, and this should be kept in mind when interpreting 
the results.

Our second approach for exploring spillover effects exploits the municipality level randomization of the Pantawid Pamilya program, following Labonne (2013). As described in Section 3, the first step of the randomization procedure selected 8 out of 19 municipalities to be part of the village-level experiment. Half of the villages in these 8 municipalities were selected to receive transfers in 2009 while the other half was delayed until 2011. The other 11 municipalities began receiving transfers in all of their villages starting in 2009. This setup allows us to estimate the effect of full implementation of the Pantawid Pamilya program at the municipality level against the counterfactual of partial implementation in half of the villages. This approach was previously used by Labonne (2013) to estimate the effect of the program on electoral support for incumbent mayors. If there were no spillovers across villages, we would expect municipalities with full implementation to experience a decrease in conflict relative to those with partial implementation.

Table 12 presents estimates of the program's effect at the municipality level, based on a difference-in-differences regression similar to that described in equation 2, but with the municipality-month as the unit of observation. The results show that municipalities with full implementation experienced a decrease in conflict incidents in the post-randomization period and the late implementation period, but an increase in the early implementation period. However, these effects are largely not statistically significant; the only exception being the decrease in the probability of experiencing any incident in the late program period, which is significant at the 10 percent level. Unfortunately, the large standard errors of the estimates make the results of this analysis largely inconclusive - we can rule out neither large conflictincreasing nor large conflict-decreasing effects of the program at the municipality level. For our spillover analysis, this means that we cannot rule out the possibility that the program's village-level effect was due to displacement of conflict from treatment to control villages. ${ }^{21}$

\footnotetext{
${ }^{21}$ We do not have access to insurgent influence data for the 11 municipalities that were not part of the
} 


\section{Conclusion}

This paper presents an experimental evaluation of the effect of a large conditional cash transfer (CCT) program - the Philippines' Pantawid Pamilya - on the intensity of violence and local insurgent influence in civil conflict. In the last decade CCT programs have become one of the most popular tools for delivering development aid and a large literature documents their positive impacts on the well being of the poor. CCT programs are currently operating in numerous conflict-affected countries including Colombia, India, Indonesia and the Philippines. This study provides novel experimental evidence of how CCT programs can affect civil conflict.

The results of our analysis indicate two key findings. First, the Pantawid Pamilya program caused a substantial reduction in the number of conflict-related incidents in the program area. Second, the program reduced insurgent influence in treated villages. This effect is important from a program-evaluation perspective, because insurgent influence can have negative consequences even in the absence of overt violence, for example by eroding the rule of law and restricting civilians' access to markets and employment (Berman et al., 2011b). A program that reduces violence by weakening insurgent influence is therefore likely to have more beneficial long-term effects than a program whose impact is limited to reducing insurgents' incentives to commit acts of violence but does not affect their influence. This finding makes an important contribution as the extant literature on development and conflict focuses almost entirely on measures of violence as the outcome of interest (e.g Miguel et al., 2004; Berman et al., 2011a; Dube and Vargas, 2013; Crost et al., 2014; Nunn and Qian, 2014). ${ }^{22}$ This paper provides important empirical evidence of the effect of an aid program on a direct measure of insurgent influence.

village-level experiment and can therefore not estimate the program's effect on insurgent influence.

${ }^{22}$ A notable exception comes from Blattman and Annan (2014) who find that an agricultural training and capital investment program reduced individuals' interactions with mercenary recruiters. 
Our results are consistent with previous findings that positive economic shocks reduce civil conflict (Miguel et al., 2004; Dube and Vargas, 2013). We are aware of three potential mechanisms through which this effect might operate. First, CCT programs may increase popular support for the government by "winning hearts and minds." As a result, the population is more likely to provide information on insurgents to government forces, better enabling them to capture or kill insurgents and reduce insurgent attack rates (Berman et al., 2011a). This mechanism is consistent with the finding that the Pantawid Pamilya program increased support for incumbent politicians (Labonne, 2013). ${ }^{23}$ Second, cash transfers may enable households in treated villages to pay so-called "revolutionary taxes" to insurgents. Failure to pay these taxes is a main reason for punitive violence against civilians, so that an improvement in household income may reduce insurgent-on-civilian violence by enabling more households to give in to extortion by insurgents. Finally, CCT programs may increase the opportunity cost of joining an insurgency. This could be either because the transfers boost the local economy and create higher incomes from peaceful activities or because the conditions imposed on program participants make it difficult to receive transfers while being active in the insurgency. ${ }^{24}$ However, this mechanism is perhaps less likely to explain our results since treatment and control villages are located close to each other and insurgents can move with relative ease between villages. It is therefore likely that a decrease in recruitment in treatment villages would have almost equal effects on incidents in treatment and control villages, and would be difficult to detect with this type of experimental setup. Whatever the mechanism, our results provide evidence that the effect of CCTs differs from the effect of other types of aid interventions, like community-driven development (CDD) and food aid

\footnotetext{
${ }^{23}$ Manacorda et al. (2011) found similar evidence that a CCT program increased popular support for the incumbent president in Uruguay.

${ }^{24}$ The conditions for receiving transfers through the Pantawid Pamilya program, for example, created incentives for families to insure none of their members were - or appeared to be - active in an armed insurgency. A senior government official responsible for the program's implementation recounted a case from the volatile Basilan province in the south of the country where spouses pressured their husbands to turn in their firearms lest they be considered incriminating evidence of affiliation with a rebel group and threaten their continued eligibility for cash transfers. (Interview with DSWD officials in Quezon City, Philippines April 2012).
} 
programs, which have been found to increase the lethality and incidence of conflict (Crost et al., 2014; Nunn and Qian, 2014).

Of particular interest is a comparison with the results of Crost et al. (2014), who found that a large-scale CDD program, KALAHI-CIDSS, increased local conflict in the Philippines. KALAHI-CIDSS took place at a similar time (2003-2009) and in similar geographic regions as the Pantawid Pamilya experiment studied in the present paper. Furthermore, both programs were implemented by the same agency, the Philippine government's Department of Social Welfare and Development. It is therefore unlikely that the opposite effects of these two programs are entirely due to institutional differences or differences in the local intensity or characteristics of the conflict.

Crost et al. (2014) argue that the KALAHI-CIDSS program increased local conflict in the Philippines because of a strategic response by insurgents. If successful aid programs increased popular support for the government as suggested by the "hearts-and-minds" hypothesis, insurgents have an incentive to sabotage the programs in order to prevent such a shift in public opinion, and this leads to increased exacerbate conflict at least in the short run. ${ }^{25}$ It is possible that CCT programs do not have this effect because they are more difficult to derail. CDD programs set up a series of public community meetings and build new infrastructure - both of which are targets that insurgents can attack in their efforts to derail the program. CCT programs such as Pantawid Pamilya, on the other hand disburse aid directly to households, primarily through electronic transfers to beneficiaries' bank accounts, which makes derailing the program more difficult. ${ }^{26}$ In support of this hypothesis, there is anecdotal evidence, reported by Crost et al. (2014) that insurgents were able to derail implementation of the KALAHI-CIDSS program in a number of areas, but we are not aware of analogous

\footnotetext{
${ }^{25}$ See Powell (2012) for a theoretical discussion of how shifts in power can cause conflict.

${ }^{26} \mathrm{It}$ is, however, possible that CCT programs create incentives to attack local bank branches on days when many program participants withdraw their transfers. If the bank branch is not in the treatment village, the experiment studied in this paper will not be able to detect this effect.
} 
evidence for the Pantawid Pamilya program. Of course, many other explanations for the difference in effects between the two types programs are possible. For example, it is possible that the cash transfers reduced insurgent-on-civilian violence by enabling more households to pay "revolutionary taxes" to insurgents.

Several limitations of our study should, however, be kept in mind. The experiment was not designed to study the effect of Pantawid Pamilya on conflict and therefore has a smaller sample size than would be optimal for such a study. Given the low baseline intensity of the conflict, our estimates are therefore necessarily based on a small number of incidents and this should be kept in mind when interpreting our estimates. Second, our municipality level estimates of the program's effect are inconclusive, so that we cannot rule out that the reduction of conflict at the village level is due to displacement of insurgent activity from treated to control villages. Further research is needed to explore whether conditional cash transfers are able to reduce aggregate conflict at higher geographical levels. Still, our findings provide suggestive evidence that the mechanism in which aid is disbursed can determine its impact on civil conflict. Going forward, this suggests opportunities for future research on how and under what conditions various means of targeting and delivering aid can reduce rather than exacerbate the risk of violent conflict.

\section{References}

Abadie, Alberto and Javier Gardeazabal, "The economic costs of conflict: A case study of the Basque Country," American Economic Review, 2003, 93 (1), 113-132.

Arulpragasam, Jehan, Luisa Fernandez, Yasuhiko Matsuda, Rosechin Olfindo, and Matt Stephens, "Building Governance and Anti-Corruption in the Philippines' Conditional Cash Transfer Program," The World Bank Group Philippine Social Protection 
Note, March 2011, (1), 1-8.

Beath, Andrew, Fotini Christia, and Ruben Enikolopov, "Institutional Design and Elite Capture: Experimental Evidence on Local Governance in Afghanistan," October 2011.

Berman, Eli, Ethan Kapstein Joseph Felter, and Erin Troland, "Predation, Economic Activity and Violence: Evidence from the Philippines," NBER Working Paper, $2012,18375$.

_, Jacob N. Shapiro, and Joseph H. Felter, "Can Hearts and Minds Be Bought? The Economics of Counterinsurgency in Iraq," Journal of Political Economy, August 2011, 119 (4), 766-819.

_, Joseph Felter, Jacob N. Shapiro, and Erin Troland, "Modest, Secure and Informed: Successful Development in Conflict Zones," American Economic Review, 2013, $103(2)$.

_, Michael Callen, Joseph H. Felter, and Jacob N. Shapiro, "Do Working Men Rebel? Insurgency and Unemployment in Afghanistan, Iraq, and the Philippines," Journal of Conflict Resolution, 2011, 55 (4), 496-528.

Blattman, Christopher and Edward Miguel, "Civil War," Journal of Economic Literature, 2010, $48(1), 3-57$.

_ and Jeannie Annan, "Can Employment Reduce Lawlessness and Rebellion? A Field Experiment with High-Risk Men in a Fragile State," 2014.

Camacho, A., "Stress and birth weight: Evidence from terrorist attacks," American Economic Review, 2005, 98 (2), 511-515.

Chaudhury, Nazmul, Jed Friedman, and Junko Onishi, "Philippines Conditional Cash Transfer Program Impact Evaluation 2012," 2013. 
Chioda, Laura, Joao M. P. de Mello, and Rodrigo R. Soares, "Spillovers from Conditional Cash Transfer Programs: Bolsa Famlia and Crime in Urban Brazil," IZA Working Paper, 2012, 6371.

Condra, Luke and Jacob N. Shapiro, "Who Takes the Blame? The Strategic Effects of Collateral Damage," American Journal of Political Science, 2012, 56 (1), 167-187.

Crost, Benjamin, Joseph H. Felter, and Patrick B. Johnston, "Aid Under Fire: Development Projects and Civil Conflict," American Economic Review, 2014, 104 (6), 1833-1856.

Dube, Oeindrila and Juan Vargas, "Commodity Price Shocks and Civil Conflict: Evidence from Colombia," Review of Economic Studies, 2013, 80 (4), 1384-1421.

Fearon, James, "Economic Development, Insurgency, and Civil War," in Elhanan Helpman, ed., Institutions and Economic Performance, Harvard University Press, 2008.

Fearon, James D. and David D. Laitin, "Ethnicity, Insurgency, and Civil War," American Political Science Review, February 2003, 97 (1), 75-90.

Felter, Joseph, "Recruitment for Rebellion and Terrorism in the Philippines," in James Forest, ed., The Making of a Terrorist: Recruitment, Training and Root Causes, Praeger International, 2006.

Fernandez, Luisa and Rosechin Olfindo, "Overview of the Philippines' Conditional Cash Transfer Program: The Pantawid Pamilyang Pilipino Program (Pantawid Pamilya)," World Bank Philippine Social Protection Note No. 2, May 2011.

Fetzer, Thiemo, "Can Workfare Programs Moderate Violence? Evidence from India," 2014.

Fiszbein, Ariel and Norbert Schady, "Conditional Cash Transfers - Reducing Present and Future Poverty," World Bank Policy Research Report, 2009. 
Ghobarah, H.A., Paul Huth, and Bruce Russett, "The Post-War Public Health Effects of Civil Conflict," Social Science 83 Medicine, 2004, 59 (4), 869-884.

International Crisis Group, "The Communist Insurgency in the Philippines: Tactics and Talks," Asia Report, 2011, 202.

Kalyvas, Stathis, The Logic of Violence in Civil War, Cambridge University Press, New York, 2006.

Khanna, Gaurav and Laura Zimmermann, "Fighting Maoist violence with promises: Evidence from India's Employment Guarantee Scheme," Economics of Peace and Security Journal, 2014, 9 (1), 30-36.

Labonne, Julien, "The Local Electoral Impacts of Conditional Cash Transfers: Evidence from a Field Experiment," Journal of Development Economics, 2013, 104, 73-88.

Leon, Gianmarco, "Civil Conflict and Human Capital Accumulation: The Long Term Effects of Political Violence in Peru," Journal of Human Resources, 2012, 47 (4), 9911022.

Lopez, H. and Q. Wodon, "The economic impact of armed conflict in Rwanda," Journal of African Economies, 2005, 14 (4), 586-602.

Manacorda, M., T. Miguel, and A. Vigorito, "Government Transfers and Political Support," American Economic Journal: Applied Economics, 2011, 3 (3), 1-28.

Mansour, Hani and Daniel I. Rees, "Armed conflict and Birth Weight: Evidence from the al-Aqsa Intifada," Journal of Development Economics, 2012, 1 (99), 190-199.

Miguel, Edward and Michael Kremer, "Worms: Identifying Impacts on Education and Health in the Presence of Treatment Externalities," Econometrica, 2004, 72 (1), 159-217. 
Miguel, Edward, Shanker Satyanath, and Ernest Sergenti, "Economic Shocks and Civil Conflict: An Instrumental Variables Approach," The Journal of Political Economy, August 2004, $112(4), 725-753$.

Murdoch, James C. and Todd Sandler, "Civil Wars and Economic Growth: Spatial Dispersion," American Journal of Political Science, 2004, 48 (1), 138-151.

Nunn, Nathan and Nancy Qian, "U.S. Food Aid and Civil Conflict," American Economic Review, 2014, 104 (6), 1630-1666.

Powell, Robert, "Persistent Fighting and Shifting Power," American Journal of Political Science, 2012, 56 (3), 620-637.

Quimpo, Nathan Gilbert, "Revolutionary Taxation and the Logistical and Strategic Dilemmas of the Maoist Insurgency in the Philippines.," Journal of Asian Security and International Affairs, 2014, 1 (3), 263-287.

Redaelli, Silvia, "Impact Evaluation on Conditional Cash Transfer Program," Social Welfare and Development Journal, January-March 2009, 3 (1), 17-24.

UNHCR, "An Introduction to Cash-Based Interventions in UNHCR Operations," 2012.

Usui, Norio, "Searching for Effective Poverty Interventions: Conditional Cash Transfer in the Philippines," Asian Development Bank, September 2011, pp. 1-18.

Weinstein, Jeremy M, Inside Rebellion: The Politics of Insurgent Violence, New York: Cambridge University Press, 2006.

Weintraub, Michael, "Do All God Things Go Together? Development Assistance and Violence in Insurgency," 2014.

World Bank, "World Development Report 2011: Conflict, Security, and Development," 2012. 


\section{Figures and Tables}

Figure 1: Map of Pantawid Pamilya Study Areas

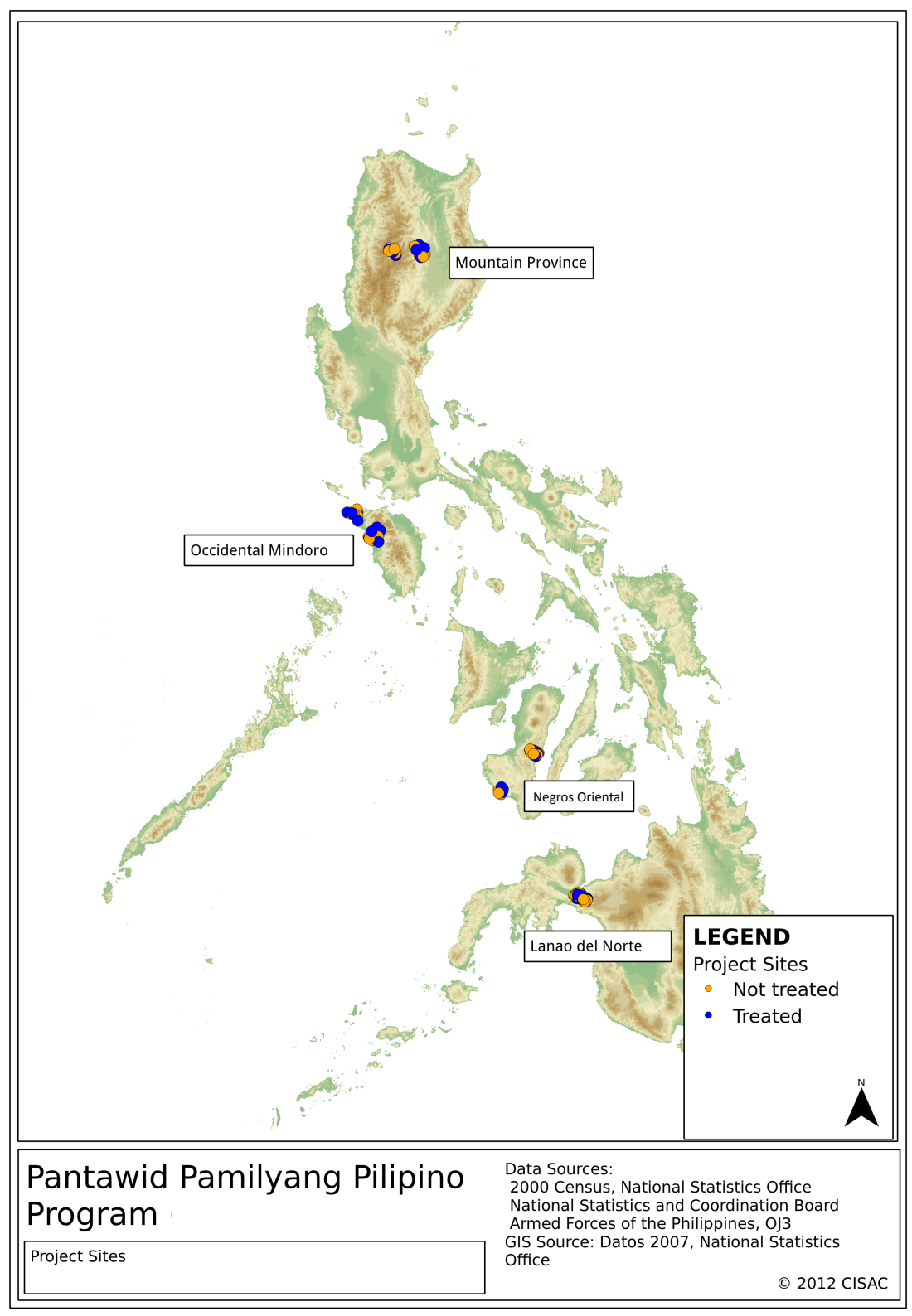




\section{Figure 2: Histogram of Incident Counts}

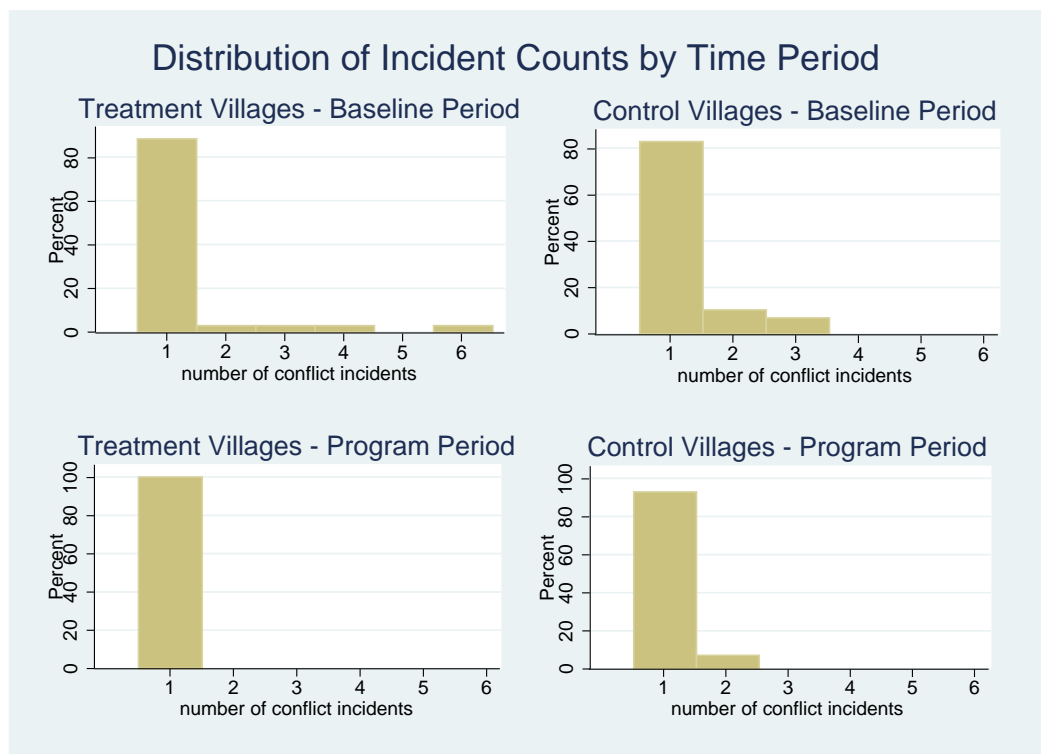

Distribution of positive monthly incident counts in experimental villages in the period 2001-2010. 
Figure 3: Time Trends of Conflict in Treatment and Control Villages

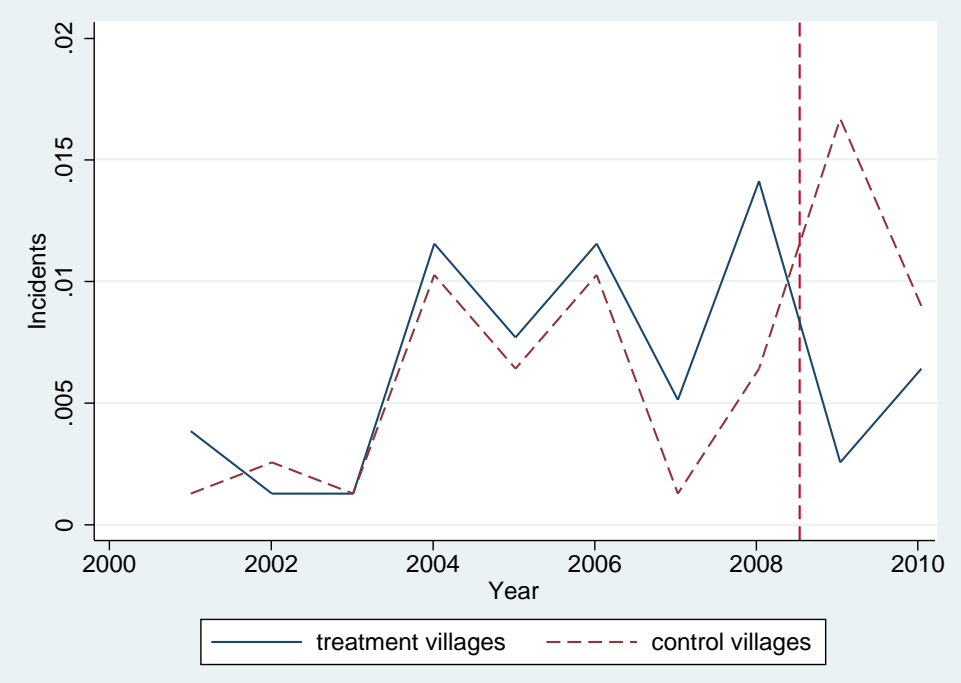

Table 1: Prevalence of Armed Groups in the Philippines, 2001-2010

\begin{tabular}{lcc}
\hline Group & Nationwide & Experimental \\
\hline NPA & $60 \%$ & $72 \%$ \\
MILF & $11 \%$ & $10 \%$ \\
LE & $19 \%$ & $18 \%$ \\
ASG & $5 \%$ & $0 \%$ \\
Other & $5 \%$ & $0 \%$ \\
\hline Total & $100 \%$ & $100 \%$ \\
\hline
\end{tabular}


Table 2: 4Ps Experimental SAmple

\begin{tabular}{lcccc}
\hline \hline Region & Province & Municipality & Treatments & Controls \\
\hline CAR & Mountain Province & Paracelis & 4 & 5 \\
CAR & Mountain Province & Sadanga & 4 & 4 \\
Region IV-B & Occidental Mindoro & Paluan & 6 & 6 \\
Region IV-B & Occidental Mindoro & Santa Cruz & 5 & 6 \\
Region VII & Negros Oriental & Jimalalud & 15 & 13 \\
Region VII & Negros Oriental & Basay & 5 & 5 \\
Region X & Lanao del Norte & Lala & 13 & 14 \\
Region X & Lanao del Norte & Salvador & 13 & 12 \\
\hline
\end{tabular}

Table 3: Description of Common Incident Types

\begin{tabular}{ll}
\hline \hline Incident & Description \\
\hline Encounter & Firefight resulting not from deliberate attack, raid or ambush. \\
Harrassment & Attack not designed to destroy or defeat enemy forces, seize or secure terrain. \\
Confiscation & Seizure of illegal material(s) discovered during combat, CMO, \\
& intelligence or SOT operation from person(s) without firefight. \\
Liquidation & Killing of AFP, Philippine National Police (PNP) or civilian official in furtherance \\
& of a political ideology. \\
Ambush & Form of attack from concealed position on moving or temporarily halted enemy. \\
\hline \hline
\end{tabular}


Table 4: Summary Statistics And Balance Tests

\begin{tabular}{lccc}
\hline \hline Variable & Treatment & Control & $P$-Value of Difference \\
\hline Conflict Incidents & 0.0065 & 0.0051 & 0.64 \\
Any conflict incident & 0.0051 & 0.0045 & 0.75 \\
Population & 1475 & 1419 & 0.81 \\
Paved Streets & 0.215 & 0.323 & 0.17 \\
Highway Access & 0.477 & 0.523 & 0.60 \\
Communal Water System & 0.169 & 0.154 & 0.81 \\
Electricity & 0.554 & 0.662 & 0.21 \\
Health Clinic & 0.462 & 0.492 & 0.73 \\
Hospital & 0.031 & 0.046 & 0.65 \\
\hline Observations & 65 & 65 & 130 \\
\hline \hline
\end{tabular}

Summary statistics and balance tests of conflict incidents and village level control variables. The conflict incidents variable is the monthly average over the pre-treatment period. All other variables are from the 2000 National Census of the Philippines. 
Table 5: The Causal Effect of the 4Ps Program on Civil Conflict: Experimental Estimates

\begin{tabular}{lcccc}
\hline \hline & \multicolumn{5}{c}{ Dependent Variable: } \\
& Number & of & Incidents & \multicolumn{2}{c}{ Any Incidents } \\
Treatment $\times$ Pre-Implementation & $(1)$ & $(2)$ & $(3)$ & $(4)$ \\
& 0.0019 & -0.00001 & 0.0011 & -0.0002 \\
& $(0.0023)$ & $(0.002)$ & $(0.0017)$ & $(0.0064)$ \\
Treatment $\times$ Post-Announcement & 0.0016 & -0.0003 & 0.0021 & 0.0008 \\
& $(0.014)$ & $(0.014)$ & $(0.0065)$ & $(0.0064)$ \\
Treatment $\times$ Early Implementation & $-0.012^{* *}$ & $-0.014^{* *}$ & $-0.010^{* *}$ & $-0.011^{* *}$ \\
& $(0.0059)$ & $(0.0060)$ & $(0.0051)$ & $(0.0052)$ \\
Treatment $\times$ Late Implementation & -0.0026 & -0.0045 & -0.0026 & -0.0039 \\
& $(0.0064)$ & $(0.0063)$ & $(0.0064)$ & $(0.0064)$ \\
\hline Control Variables & No & Yes & No & Yes \\
\hline Villages & 130 & 130 & 130 & 130 \\
\hline \hline
\end{tabular}

The unit of observation is the village-month. All specifications include month fixed effects as well as municipality fixed effects interacted with indicators for the four time-periods. Control variables are village population and indicators for the presence of paved streets, electricity, a communal water system, one or more health clinics or hospitals. Standard errors are clustered at the village level. $*{ }^{* *}$ and $* * *$ denote statistical significance at the $10 \%, 5 \%$ and $1 \%$ levels.

Table 6: The Causal Effect of the 4Ps Program on Civil Conflict: Difference-in-Differences Estimates

\begin{tabular}{|c|c|c|c|c|c|c|}
\hline & \multicolumn{3}{|c|}{ Number of Incidents } & \multicolumn{3}{|c|}{ Any Incidents } \\
\hline & \multicolumn{3}{|c|}{ Baseline Conflict: } & & \multicolumn{2}{|c|}{ Baseline Conflict: } \\
\hline & $\begin{array}{l}\text { Whole Sample } \\
\text { (1) }\end{array}$ & $\begin{array}{c}\text { Low } \\
(2)\end{array}$ & $\begin{array}{c}\text { High } \\
(3)\end{array}$ & $\begin{array}{l}\text { Whole Sample } \\
\text { (4) }\end{array}$ & $\begin{array}{l}\text { Low } \\
(5)\end{array}$ & $\begin{array}{c}\text { High } \\
(6)\end{array}$ \\
\hline Treatment $\times$ Post-rand./Pre-imp. period & $\begin{array}{l}0.0003 \\
(0.017)\end{array}$ & $\begin{array}{c}0.014 \\
(0.022)\end{array}$ & $\begin{array}{l}-0.023 \\
(0.021)\end{array}$ & $\begin{array}{c}0.0010 \\
(0.0070)\end{array}$ & $\begin{array}{l}0.0065 \\
(0.010)\end{array}$ & $\begin{array}{l}-0.0079 \\
(0.0078)\end{array}$ \\
\hline Treatment $\times$ Early implementation period & $\begin{array}{r}-0.014^{* *} \\
(0.0060)\end{array}$ & $\begin{array}{l}-0.012^{*} \\
(0.0073)\end{array}$ & $\begin{array}{l}-0.016 \\
(0.010)\end{array}$ & $\begin{array}{r}-0.011^{* *} \\
(0.0051)\end{array}$ & $\begin{array}{c}-0.0095^{* *} \\
(0.0045)\end{array}$ & $\begin{array}{c}-0.014 \\
(0.0099)\end{array}$ \\
\hline Treatment $\times$ Late implementation Period & $\begin{array}{l}-0.0045 \\
(0.0064)\end{array}$ & $\begin{array}{l}-0.0078 \\
(0.0089)\end{array}$ & $\begin{array}{c}0.0008 \\
(0.0072)\end{array}$ & $\begin{array}{l}-0.0037 \\
(0.0067)\end{array}$ & $\begin{array}{l}-0.0078 \\
(0.0085)\end{array}$ & $\begin{array}{c}0.0028 \\
(0.0070)\end{array}$ \\
\hline F-Test effect in total implementation period $=0$ & $4.14^{* *}$ & $3.25^{*}$ & 1.31 & $3.27^{*}$ & $3.39^{*}$ & 0.83 \\
\hline Observations & 15600 & 9600 & 6000 & 15600 & 9600 & 6000 \\
\hline Villages & 130 & 80 & 50 & 130 & 80 & 50 \\
\hline
\end{tabular}

The unit of observation is the village-month. All specifications include village and municipality-by-month fixed effects. Standard errors are clustered at the municipality-year level. Low (high) baseline conflict areas are defined as municipalities with a below (above) median number of incidents in the pre-program period. *,** and *** denote statistical significance at the $10 \%, 5 \%$ and $1 \%$ levels. 


\section{Table 7: Robustness to Definitions of Early and Late Treatment Period}

\begin{tabular}{|c|c|c|c|c|c|c|}
\hline & \multicolumn{6}{|c|}{ Cutoff for Early Imp. Period: } \\
\hline & $\begin{array}{c}3 \text { months } \\
\text { (1) }\end{array}$ & $\begin{array}{c}6 \text { months } \\
(2)\end{array}$ & $\begin{array}{c}9 \text { months } \\
(3)\end{array}$ & 12 months & 15 months & 18 months \\
\hline \multicolumn{7}{|c|}{ Panel A - Dependent Variable: Number of Incidents } \\
\hline Treatment $\times$ Early implementation period & $\begin{array}{c}-0.022^{* *} \\
(0.010)\end{array}$ & $\begin{array}{l}-0.015^{*} \\
(0.0077)\end{array}$ & $\begin{array}{c}-0.014^{* *} \\
(0.060)\end{array}$ & $\begin{array}{c}-0.0095 * \\
(0.0054)\end{array}$ & $\begin{array}{c}-0.011^{* *} \\
(0.0055)\end{array}$ & $\begin{array}{c}-0.0095^{* *} \\
(0.0047)\end{array}$ \\
\hline Treatment $\times$ Late implementation Period & $\begin{array}{c}-0.0062 \\
(0.0049)\end{array}$ & $\begin{array}{c}-0.0061 \\
(0.0053)\end{array}$ & $\begin{array}{c}-0.0045 \\
(0.0064)\end{array}$ & $\begin{array}{c}-0.0072 \\
(0.0063)\end{array}$ & $\begin{array}{c}-0.0022 \\
(0.0048)\end{array}$ & $\begin{array}{l}-0.0025 \\
(0.0082)\end{array}$ \\
\hline \multicolumn{7}{|c|}{ Panel B - Dependent Variable: Any Incidents } \\
\hline Treatment $\times$ Early implementation period & $\begin{array}{c}-0.016^{* *} \\
(0.0065)\end{array}$ & $\begin{array}{l}-0.011^{*} \\
(0.0065)\end{array}$ & $\begin{array}{c}-0.011^{* *} \\
(0.051)\end{array}$ & $\begin{array}{c}-0.0073 \\
(0.0047)\end{array}$ & $\begin{array}{c}-0.0092^{*} \\
(0.0053)\end{array}$ & $\begin{array}{c}-0.0078^{*} \\
(0.0045)\end{array}$ \\
\hline Treatment $\times$ Late implementation Period & $\begin{array}{c}-0.0055 \\
(0.0051)\end{array}$ & $\begin{array}{c}-0.0053 \\
(0.0056)\end{array}$ & $\begin{array}{c}-0.0037 \\
(0.0067)\end{array}$ & $\begin{array}{c}-0.0064 \\
(0.0069)\end{array}$ & $\begin{array}{c}-0.0014 \\
(0.0040)\end{array}$ & $\begin{array}{l}-0.0017 \\
(0.0075)\end{array}$ \\
\hline Observations & 15600 & 15600 & 15600 & 15600 & 15600 & 15600 \\
\hline Villages & 130 & 130 & 130 & 130 & 130 & 130 \\
\hline
\end{tabular}

The unit of observation is the village-month. All specifications include village and municipality-by-month fixed effects. Standard errors are clustered at the municipality-year level. Low (high) baseline conflict areas are defined as municipalities with a below (above) median number of incidents in the pre-program period. *, ** and *** denote statistical significance at the $10 \%, 5 \%$ and $1 \%$ levels.

Table 8: Conditional Cash Transfers and Insurgent Influence

\begin{tabular}{lcccc}
\hline \hline & & \multicolumn{2}{c}{ Dependent Variable: } & \\
& $\begin{array}{c}\text { Insurgent Influence } \\
\text { Ordered Probit }\end{array}$ & $\begin{array}{c}\text { Influence } \geq 1 \\
\text { OLS }\end{array}$ & $\begin{array}{c}\text { Influence } \geq 2 \\
\text { OLS }\end{array}$ & $\begin{array}{c}\text { Influence }=3 \\
\text { OLS }\end{array}$ \\
& $(1)$ & $(2)(3)$ & $(4)$ & \\
\hline Treatment & $-0.54^{* *}$ & -0.057 & -0.011 & -0.016 \\
& $(0.25)$ & $(0.048)$ & $(0.016)$ & $(0.012)$ \\
\hline Observations & 260 & 260 & 260 & 260 \\
Villages & 130 & 130 & 130 & 130 \\
\hline \hline
\end{tabular}

The dependent variable is an ordered categorical measure of insurgent influence, coded on a scale from 0 to 3 , as described in Section 4.1. The unit of observation is the village-year. All specifications include municipality and year fixed effects and control for village population, as well as indicators for the presence of paved streets, electricity, a communal water system, one or more health clinics or hospitals. Standard errors are clustered at the village level. $*, * *$ and $* * *$ denote statistical significance at the $10 \%, 5 \%$ and $1 \%$ levels. 
Table 9: The Effect of Pantawid Pamilya on the Number of Casualties: Difference-inDifferences Estimates

\begin{tabular}{lcc}
\hline \hline & \multicolumn{2}{c}{ Dependent Variable } \\
& \# of Casualties & Any Casualties \\
$(1)$ & $(2)$ \\
\hline Treatment $\times$ Post-rand./Pre-imp. period & 0.0069 & 0.0019 \\
& $(0.0084)$ & $(0.0044)$ \\
Treatment $\times$ Early implementation period & -0.0009 & 0.0015 \\
& $(0.0032)$ & $(0.0017)$ \\
Treatment $\times$ Late implementation Period & -0.0026 & -0.0002 \\
& $(0.0027)$ & $(0.0009)$ \\
\hline Mean of dependent variable & & \\
& 0.0024 & 0.0011 \\
\hline Observations & {$[0.109]$} & {$[0.033]$} \\
Villages & 15600 & 15600 \\
\hline \hline
\end{tabular}

The unit of observation is the village-month. All specifications include village and municipality-by-month fixed effects. Standard errors, clustered at the municipality-year level, are reported in parenthesis. ${ }^{*},{ }^{* *}$ and $* * *$ denote statistical significance at the $10 \%, 5 \%$ and $1 \%$ levels. Standard deviations of the dependent variables are reported in square brackets. 
Table 10: Spillover Effects to Nearby Villages

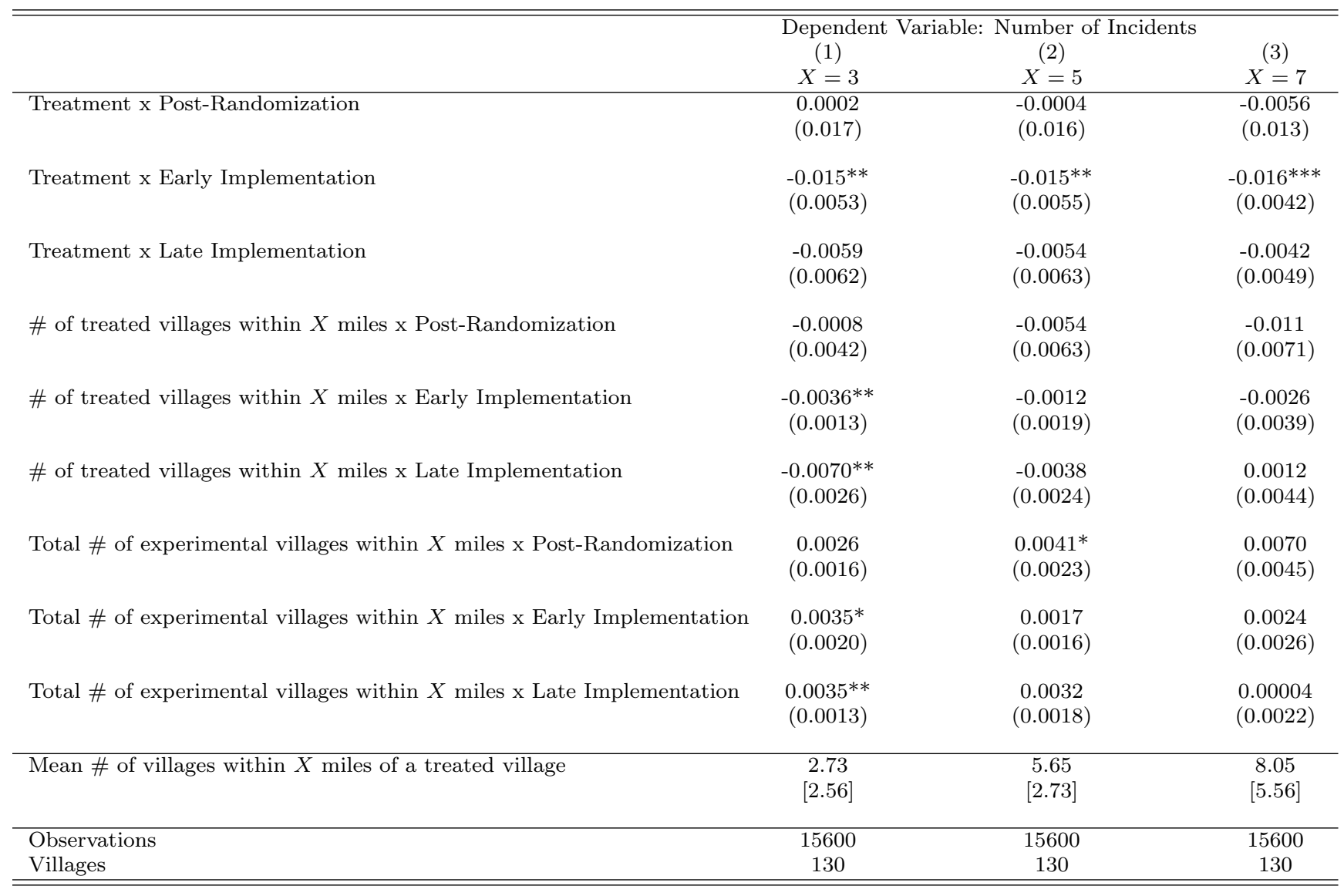

The unit of observation is the village-month. All specifications include village and municipality-by-month fixed effects. Standard errors are clustered at the municipality-year level, reported in parenthesis $*, * *$ and $* * *$ denote statistical significance at the $10 \%, 5 \%$ and $1 \%$ levels. Standard deviations of means are reported in square brackets. 
Table 11: Conditional Cash Transfers and Insurgent Influence: Spillover Analysis

\begin{tabular}{lccccccc}
\hline \hline & \multicolumn{3}{c}{ Dependent Variable: } \\
& \multicolumn{3}{c}{ Insurgent Influence } & \multicolumn{3}{c}{ Influence $\geq 1$} \\
& $(1)$ & $(2)$ & $(3)$ & $(4)$ & $(5)$ & $(6)$ \\
\hline Treatment & $-0.77^{* *}$ & $-0.58^{*}$ & $-0.51^{* *}$ & -0.061 & -0.0052 & -0.069 \\
& $(0.33)$ & $(0.26)$ & $(0.26)$ & $(0.047)$ & $(0.046)$ & $(0.056)$ \\
& & & & & & \\
& & & & & \\
& $-0.63^{* * *}$ & -0.26 & -0.009 & $-0.040^{* *}$ & -0.035 & -0.035 \\
& $(0.21)$ & $(0.19)$ & $(0.16)$ & $(0.020)$ & $(0.022)$ & $(0.021)$ \\
Total \# of treated villages within $X$ & & & & & & \\
& $0.26^{*}$ & 0.0062 & -0.081 & 0.013 & 0.0081 & 0.014 \\
& $(0.15)$ & $(0.12)$ & $(0.12)$ & $(0.009)$ & $(0.013)$ & $(0.021)$ \\
\hline Observations & & & & & & \\
Villages & 260 & 260 & 260 & 260 & 260 & 260 \\
\hline \hline
\end{tabular}

The dependent variable is an ordered categorical measure of insurgent influence, coded on a scale from 0 to 3 , as described in Section 4.1. The unit of observation is the village-year. All specifications include municipality and year fixed effects and control for village population, as well as indicators for the presence of paved streets, electricity, a communal water system, one or more health clinics or hospitals. Standard errors are clustered at the village level. $*, * *$ and $* * *$ denote statistical significance at the $10 \%, 5 \%$ and $1 \%$ levels.

Table 12: Spillover Analysis: Difference-in-Differences Estimates at the Municipality Level

\begin{tabular}{lcc}
\hline \hline & $\begin{array}{c}\text { Number of Incidents } \\
(1)\end{array}$ & $\begin{array}{c}\text { Any Incidents } \\
(2)\end{array}$ \\
\hline Full implementation $\times$ Post-rand./Pre-imp. period & -0.15 & 0.087 \\
& $(0.26)$ & $(0.11)$ \\
Full implementation $\times$ Early implementation period & 0.063 & 0.032 \\
& $(0.12)$ & $(0.063)$ \\
Full implementation $\times$ Late implementation Period & -0.13 & -0.076 \\
& $(0.11)$ & $(0.050)$ \\
\hline F-Test effect in total implementation period $=0$ & & 0.21 \\
\hline Mean of dependent variable & 0.13 & 0.078 \\
& 0.15 & {$[0.27]$} \\
\hline Observations & {$[0.75]$} & 2400 \\
Municipalities & 2400 & 19 \\
\hline \hline
\end{tabular}

The unit of observation is the municipality-month. "Full implementation" denotes the 11 municipalities in which implementation of the Pantawid Pamilya program began in all villages in 2009. The remaining 8 municipalities were randomly selected to be part of the village level experiment that delayed implementation in half of their villages until 2011. All specifications include municipality and month fixed effects. Standard errors are clustered at the municipality-year level and reported in parenthesis. ${ }^{*}, * *$ and ${ }^{* * *}$ denote statistical significance at the $10 \%, 5 \%$ and $1 \%$ levels. Standard deviations of sample means are reported in square brackets. 